Marquette University

e-Publications@Marquette

$1-1-2009$

Local Employment, Poverty, and Property Value Effects of Geographically-Targeted Tax Incentives: An Instrumental Variables Approach

Andrew Hanson

Marquette University, andrew.r.hanson@marquette.edu

Accepted version. Regional Science and Urban Economics, Vol. 39, No. 6 (November 2009): 721-731.

DOI. Published under Creative Commons license Attribution-NonCommercial-NoDerivatives 4.0 International.

Andrew Hanson was affiliated with Georgia State University at the time of publication. 


\title{
Local Employment, Poverty, and Property Value Effects of Geographically-Targeted Tax Incentives: An Instrumental Variables Approach
}

Published in Regional Science and Urban Economics, Vol. 39, No. 6 November 2009

\author{
Andrew Hanson \\ Department of Economics, Georgia State University \\ P.O. Box 3992 \\ Atlanta, GA 30302 \\ ahanson@gsu.edu
}

\begin{abstract}
:
The federal Empowerment Zone (EZ) program is a set of tax incentives targeted to areas of select cities. I estimate the effect of the EZ program on employment, poverty, and property values by comparing areas that received an EZ to areas that applied (and qualified), but were rejected. Because of endogeneity concerns, I use political representation to instrument for EZ designation. OLS results show a positive and statistically significant effect of the program on employment and poverty. IV estimates suggest the program had no effect on employment and poverty, and instead had a large statistically significant effect on property values.
\end{abstract}

JEL Classification: H25; H53; H43; R5; J38

Keywords: Empowerment zone; Regional policy; Wage subsidy; Poverty reduction

I would like to thank Stacy Dickert-Conlin, Pete Wilcoxen, John Yinger, Jeff Kubik, Jeff Clemens, Geoffrey Turnbull, Daniel McMillen, and an anonymous referee for helpful comments and suggestions. I would also like to thank administrators at the Department of Housing and Urban Development for assistance with data collection. 


\section{Introduction}

Geographically-targeted tax incentives are an increasingly popular policy for economic redevelopment. The first federal tax incentive with a geographic targeting mechanism, the Empowerment Zone (EZ) program, began in 1995 as the start of a decade-long trend toward using the federal tax code to subsidize areas experiencing economic hardship. In addition to the nine original EZs, Congress established 29 new zones since 1997. The Office of Management and Budget estimates that in terms of foregone revenue, geographically-targeted tax incentives will cost $^{1} \$ 1.7$ billion in fiscal year 2009 and $\$ 4.8$ billion for 2009-2013 (Executive Office of the President, 2008). ${ }^{2}$ Despite the growing popularity of geographically-based tax incentives among policy makers, there is not a consensus about how they affect targeted populations.

I use the federal EZ program to test the effect of geographically-based tax incentives on local employment, resident poverty rates, and median property values. Previous estimates of the federal EZ program, Busso and Kline (2006) and HUD (2001), find large positive effects on employment and large negative effects on poverty rates; however both of these studies treat EZ assignment as strictly exogenous. Krupka and Noonan (2009) estimate a substantial positive effect of the federal EZ program on local property values, a result that is robust to several specifications, some that account for endogeneity of zone assignment. I examine potential for zone designation to be endogenous to outcomes of interest and use instrumental variables to provide estimates that correct for the potential endogeneity bias.

\footnotetext{
${ }^{1}$ Estimate includes expenditures on Empowerment Zones, Renewal Communities, Enterprise Communities, the New York Liberty Zone that was established in the wake of 9/11, the Gulf Opportunity Zone established after Hurricane Katrina, and the District of Columbia Enterprise Zone.

2 2009-2012 estimates assume that many of the Empowerment Zones will be allowed to expire at the end of 2009 making this an underestimate. Despite this caveat, these tax incentives are larger than over half of all tax expenditures in the budget for the period in terms of forgone revenue.
} 
I estimate the effect of the EZ program with two different methods. The first, an OLS differencing design, compares the relative outcomes for EZ designated areas and their surrounding city with rejected applicants and their surrounding city before and after the program. The primary assumption in the first method is that EZ designation is not correlated with expected changes in economic outcomes of interest. The second, an IV approach, uses federal political representation of local jurisdictions as an instrument for EZ designation. The primary assumption in the second method is that political representation prior to EZ designation is not correlated with changes in economic outcomes of interest.

The OLS results suggest that the EZ program has a positive and statistically significant effect on resident employment rates, and a negative and statistically significant effect on resident poverty rates. IV results suggest that the EZ program has no effect on resident employment (point estimates equal to zero), and a positive effect on resident poverty rates; however both of these results are statistically imprecise. Alternatively, IV estimates show a large, positive and statistically significant effect of the program on median property values.

The remainder of the paper begins with a brief description of the previous literature. Section III follows with an explanation of the EZ program and outlines my identification strategy. Section IV gives a summary of the demographic and economic characteristics of both the EZs

and comparison areas, before and after designation. In Section V, I describe my results using both OLS and instrumental variables regressions. Section VI concludes.

\section{Previous Studies of Geographically-Targeted Tax Incentives}

Policy makers at all levels of government have implemented a myriad of geographicallytargeted tax incentive programs during the last few decades. The incentives offered differ across 
jurisdictions; some offer tax credits for hiring or training employees in certain industries, others offer tax credits related to creating jobs, many offer incentives for capital investment. The common theme of these incentives is that they create differential tax treatment within an otherwise homogenous tax jurisdiction ${ }^{3}$ that is based on a precise physical location within that jurisdiction.

The majority of past analyses of geographically-targeted tax incentives study programs initiated at the state level, and focuses on how these programs affect employment outcomes. Papke (1994) examined the State of Indiana Enterprise Zone program that gives both capital and labor tax incentives to firms operating within the zone. She finds that unemployment claims at offices within the zone declined by 19 percent, a decline of 1,500 claims per year at the mean. Boarnet and Bogart (1996) examine the effect of the New Jersey Enterprise Zone program and find that Enterprise Zone status had no effect on employment or property values at the municipal level. O'Keefe (2004) finds that the Enterprise Zone program in California increased employment growth by 3.1 percent relative to comparison areas in the first 6 years followed by a decrease in employment growth of 3.2 percent in years 7 to 13 .

Bondonio and Engberg (2000) analyze a set of different state geographically-targeted incentives and find that they have no impact on employment. The null result is robust to different methodology and is not sensitive to the features of state programs or the value of the incentives offered. Bondonio and Greenbaum (2007) also analyze different state geographicallytargeted programs, but look for differential impacts by the status of firm. They find that geographically-targeted incentives have a positive effect on employment at new and existing firms, but these gains are offset by the loss at firms that close or leave the area.

\footnotetext{
${ }^{3}$ For instance, if all residents of a county normally faced the same tax treatment, these policies would create areas based on geography within the county that receive different tax treatment.
} 
There are three evaluations of the federal EZ, one conducted by the Department of Housing and Urban Development (HUD) in 2001, another by Busso and Kline (2006) and a more recent analysis by Krupka and Noonan (2009). The HUD study finds several positive effects on areas that received EZ designation including: growth at firms located within the EZs, an increase in the number of residents employed at firms located within the EZs, and an increase in the number of resident-owned businesses. The HUD study identifies the effect of EZs by comparing employment at firms located in the EZs to firms in areas of the city that are both similar and adjacent to the EZs before and after zone designation.

Busso and Kline (2006) use rejected applicants as a comparison group to identify the effects of EZs using a difference-in-difference methodology. The preferred estimates of Busso and Kline suggest that EZ designation is associated with a statistically significant 4.1 percentage point increase in local employment, and a 3.8 percentage point decrease in local poverty rates. Both the HUD and Busso and Kline estimation strategies rely on the assumption that EZ designation did not depend on the economic outcomes that an area would have experienced had it not been awarded EZ status (i.e. that EZ designation is exogenous).

Krupka and Noonan (2009) use future recipients of EZs as a control group to determine the effects of first round EZs on local property values. ${ }^{4}$ They address endogeneity concerns by applying the instrumental variables strategy developed in an earlier version of this paper. They find that the EZ program is responsible for a substantial increase in median property value in designated areas. The increase in property value is robust across specifications that account for endogeneity with the magnitude of these estimates ranging from a low of twenty percent to a

\footnotetext{
${ }^{4}$ They do not use a direct comparison strategy as presented here, but instead include data on all census block groups and create separate dummy variables for round $1 \mathrm{EZs}$ and all areas that ever had an EZ. This estimation strategy may suffer from multicollinearity as the round $1 \mathrm{EZ}$ variable is equal to one only when the $\mathrm{EZ}$ ever variable is also equal to one. It may also suffer from bias if the initial EZ application process was beneficial to areas.
} 
high of sixty percent. They find positive and significant effects even without accounting for endogeneity, which, when compared to the results using rejected applicants here suggests that there may be important unobserved characteristics of areas that went through the original application process.

In addition to the growing literature on Zones, there is a related literature that assesses tax increment financing (TIF) areas. The TIF concept is similar to the Zone concept in that a geographic area is set aside for special treatment within a jurisdiction; however, instead of being offered direct assistance, TIF areas are granted claim to any increase in property tax collection that results from increased property values in the designated area. The evaluation of TIFs is plagued by similar problems as the evaluation of Zones. As pointed out by Dye and Merriman (2000), identifying the effects of a TIF are especially challenging due to the fact that the value of the TIF is directly related to the growth in property values. Dye and Merriman summarize this problem with the following question: "does TIF adoption cause future growth in property values or does anticipated growth in property values cause the decision to adopt tax increment financing"?

Despite the challenges in identifying the effects of TIFs empirically, researchers have had some success. Dye and Merriman (2000) estimate the effects of TIF adoption using a selfselection treatment model to account for the endogenous designation of TIF areas. Using data from the Chicago area, they find cities that adopt TIF districts have slower property value growth than those that do not adopt TIFs. Anderson (1990) also recognizes the simultaneous nature of TIF adoption and property value growth in estimating the effects of TIFs on property values in Michigan, and estimates the effect of TIF adoption using a two-stage estimation strategy with structural Probit model. Anderson finds that cities with a growing population and higher 
predicted property values are more likely to adopt TIFs, suggesting that indeed simultaneity is a problem. Anderson comes to the opposite conclusion of Dye and Merriman about the property value impact of TIFs, he finds that cities that adopt TIFs have greater property value increases than those that do not adopt.

Part of the explanation in these contradictory findings may come from both the wide variation in the type of TIFs and the substantial spill-over effects that TIF districts have on surrounding property values in a city. Weber, Bhatta, and Merriman (2007) find that properties in Chicago located near industrially zoned TIFs experienced declines in value, while those located near commercially and residentially zoned TIFs experienced an increase in property values. See Weber, Bhatta, and Merriman (2007) for a recent, more complete review of the literature on TIFs.

\section{Program Details and OLS Identification Strategy}

The federal government began to offer tax incentives to employers located in parts of economically distressed areas with the creation of the Empowerment Zone program, ${ }^{5}$ which was passed into law as part of the 1993 Budget Reconciliation (OBRA 1993, P.L. 103-66). HUD designated 6 EZs in urban areas; the Department of Agriculture designated 3 EZs in rural areas. EZs were chosen from a group of applications made by state and local governments. Each department considered applications for areas where at least 20 percent of the population lived in poverty and 6.3 percent were unemployed (GAO, 2004). From 78 nominees (Wallace, 2004), the federal government awarded EZ status to parts of 6 cities (Atlanta, Baltimore, Chicago,

\footnotetext{
5 Given (2004) lists Alaska, Delaware, Idaho, Kansas, Montana, New Hampshire, Nevada, North Dakota, South Dakota, and Wyoming as the only states that do not have some sort of zone-based tax incentive program.
} 
Detroit, Philadelphia/Camden, New York) and 3 rural areas (Kentucky Highlands, Mississippi

Delta, and the Rio Grande Valley in Texas). Zones were established at the census tract level.

The EZ program is primarily a set of tax incentives claimed by employers who operate inside of well-defined geographic boundaries and hire residents of those areas, each tax incentive is explained in detail in the appendix. For the original urban EZs, $\$ 100$ million in the form of Social Service Block Grant funds accompanied the tax incentives. ${ }^{6}$ The largest component of the EZ program is the wage tax credit, ${ }^{7}$ which allows employers operating in the zone that hire residents of the zone to claim up to a $\$ 3,000$ tax credit per employee. Many of the nominees that did not receive EZ status were given a "runner-up" award called Enterprise Communities (EC) a less generous overall package of assistance with a limited set of tax incentives. ${ }^{8}$ The tax incentives and grant allocations for each type of designation are detailed in Table 1.

Because the nominees that were not awarded EZ status were still granted some locationspecific benefits, HUD maintained detailed boundary files at the census tract level for each city. I use a list of the census tracts for all zones obtained through personal correspondence with HUD administrators to define precise comparison and treatment areas. Key for my identification strategy, only the original EZs were allowed to claim the wage tax credit during the years of data that I use (1990-2000). Although my comparison and treatment groups differ primarily by the

\footnotetext{
${ }^{6}$ Social Service Block Grants can be used for a variety of services including: day care for children, employment services, counseling, legal services, transportation, education, and substance abuse recovery. Grant funds for each EZ are funded through the department of Health and Human Services and administered by states. $\$ 40$ million in Social Service Block Grants was awarded to rural EZs.

${ }^{7}$ According to the U.S Government Accountability Office (1999), the wage tax credit is the most-used tax incentive by zone businesses; the IRS does not report claims for any of the other zone-related incentives besides the zone facility bonds (see Hanson, 2006 for a discussion of the EZ wage tax credit use).

${ }^{8}$ The Boston, Oakland, Houston and Kansas City nominees were designated as Enhanced Enterprise Communities (EEC). EEC status gave these communities a more generous allocation of grant funds than the standard Enterprise Communities. Two nominees, Cleveland and Los Angeles, were awarded the status of Supplemental Empowerment Zone (SEZ) (GAO, 2004), which did not allow for all of the tax benefits of regular EZs, but included more generous grants than regular EZs. All of the results presented in this paper are robust to excluding the Cleveland and Los Angeles runner-up areas from the control group.
} 
availability of the wage tax credit, the treatment cities also received a larger one-time grant allocation than most of the control cities. Because I cannot separate the effect of the one-time grant from the wage tax credit, my results should be viewed as the joint effect of the grant and continued presence of the wage tax credit.

I use the census tracts for all "runner-up" designations ${ }^{9}$ as a comparison group because they were not allowed to claim the wage tax credit. To facilitate clean identification I use a tripledifference method to identify the effects of the EZ program. This strategy compares the outcomes for census tracts awarded an EZ with those that were not, both across time and with the city average. Figure 1 shows a map of the New York City EZ and the runner-up Los Angeles EC to demonstrate the triple-difference method. As an example, this method is equivalent to comparing the difference in outcomes between the New York EZ and the surrounding city of New York with those of the Los Angeles EC and the surrounding city of Los Angeles, before and after the program. This identification strategy implies that the relative change in outcomes between the Los Angeles EC and the surrounding city is what would have happened in the absence of the program between the New York EZ and the remainder of New York City.

The perfect counter-factual for measuring the effect of the EZ program would be to know what would have happened in designated areas had the EZ never been assigned there. Because the EZ must be assigned to a particular area or group of areas, this is not possible. I use the

\footnotetext{
${ }^{9}$ The runner-up group consists of parts of the following cities: Akron, OH, Albany, GA, Albany, NY, Albuquerque, NM, Birmingham, AL, Boston, MA, Bridgeport, CT, Buffalo, NY, Burlington, VT, Charleston, SC, Charlotte, NC, Cleveland, OH, Columbus, OH, Dallas, TX, Denver, CO, Des Moines, IA, East St. Louis, IL, El Paso, TX, Flint, MI, Harrisburg, PA, Houston, TX, Huntington, WV, Indianapolis, IA, Ironton, OH, Jackson, MS, Kansas City, KS, Kansas City, MO, Las Vegas, NV, Little Rock, AR, Los Angeles, CA, Louisville, KY, Lowell, MA, Manchester, NH, Memphis, TN, Miami, FL, Milwaukee, WI, Minneapolis, MN, Muskegon, MI, Nashville, TN, New Haven, CT, Newark, NJ, Newburgh, NY, Norfolk, VA, Oakland, CA, Ogden, UT, Oklahoma City, OK, Omaha, NE, Phoenix, AZ, Pittsburgh, PA, Portland, OR, Providence, RI, Rochester, NY, San Antonio, TX, San Diego, CA, San Francisco, CA, Seattle, WA, Springfield, IL, Springfield, MA, St. Louis, MO, St. Paul, MN, Tampa, FL, Waco, TX, Washington, DC, and Wilmington, DE.
} 
"runner-up" areas to provide the best possible counter-factual for EZ assignment. By using the "runner-up" areas and differencing with the larger city I can eliminate many of the concerns that arise when using simple before and after comparisons or comparisons with similar areas. Because I determine the effect of the EZ program by comparing these areas with areas that received some assistance, my results should be interpreted as the marginal effect of the assistance offered to the EZ areas (larger grants and the presence of a wage tax credit).

The differencing design isolates the effect of the EZ from both time-invariant, area-wide effects and changes in economic conditions that vary over time but affect all areas. The comparison group used is similar to the EZ areas but is not likely subject to negative (or positive) effects from the policy because they made up of tracts located in different cities than the EZs. Because both the comparison and treatment groups applied for EZ designation and met the requirements for unemployment and poverty, there will be no unobservable differences caused from going through the application process or being qualified. To reflect this strategy, the variables used in each regression are of the following form: ${ }^{10}$

$$
\text { (1) } \mathrm{Y}_{\mathrm{i}}=\left(\mathrm{Y}_{\text {tract2000 }}-\mathrm{Y}_{\text {city2000 }}\right)-\left(\mathrm{Y}_{\text {tract } 1990}-\mathrm{Y}_{\text {city } 1990}\right)
$$

The differencing methodology can be thought of as a way to control for unobserved factors that could be driving correlation between the EZ and economic outcomes causing bias. The first difference in this method (the first bracketed term in Equation (1)) eliminates any city-wide time variant variables that could be in the error term. Taking this difference eliminates any difference in economic outcomes that happen because of city-specific shocks over the decade. For

\footnotetext{
${ }^{10}$ This method of differencing does not allow me to capture the coefficients on surrounding city or pre-treatment characteristics, which may be desirable. In addition, it restricts the coefficients on the city change and pre-treatment characteristics to be equal to one. I implement this strategy instead of using these variables as controls for three reasons: first to avoid multicollinearity issues between the city and tract variables and between the city variables in different years, second to avoid using endogenous pre-treatment characteristics in the instrumental variables regression directly, and lastly for ease of interpreting the regression results as changes.
} 
example, if a city had a large manufacturing facility close in the 1990s taking this difference will remove the effect of this event on economic outcomes, leaving the effect of the EZ only, as long as the event did not affect EZ areas differentially than the larger city.

The second difference in this method (the difference between the two bracketed terms in Equation (1)) eliminates any tract-specific or city-wide fixed effects that could be responsible for changes in economic outcomes. Taking this difference eliminates any difference in economic outcomes that occurs because of the fixed attributes of a census tract or city. For example, if all tracts chosen for EZs have poor school systems, taking this difference will eliminate the possibility that the EZ variable is also picking up the effects of poor school systems on economic outcomes.

The estimating equation used to determine the effect of the EZ program on the percentage of residents employed and the percentage of residents with income below the national poverty level is:

$$
\text { (2) } Y_{i}=\alpha+\beta E Z_{i}+X^{\prime} \delta+u
$$

Where $\mathrm{i}$ indexes the census tracts, $\mathrm{X}$ is a vector of control variables, and EZ is a dummy variable for availability of the EZ wage tax credit. All variables are differenced as shown in Equation (1). The unit of observation is the census tract, and I use data from the 1990 and 2000 censuses to estimate Equation (1).

The differencing method limits the error term to being only census tract level variables that change over the decade. If there are variables that are tract-specific that change over the decade and are correlated with designation of the EZ they can still cause bias in the estimate of EZ program effects. In the results section I describe the endogeneity problem caused by omission of 
tract-specific variables that change over time and propose a solution using an instrumental variables approach.

Another potential weakness of this differencing method is that the larger city may be subject to spill-overs from the EZ policy. This problem arises when using comparison and treatment areas that are similar and geographically close, because economic activity can shift across these areas. It is also possible that the policy creates positive (negative) externalities on comparison areas, making the effect of the program look smaller (larger) than it actually is. Differencing with the entire city surrounding the EZ mutes the potential for spill-over effects because the effect of the EZ on specific census tracts is averaged in with other census tracts that are not likely to be changed by the presence of an EZ. If there are positive (negative) general equilibrium effects for the city surrounding the EZ, then the estimates presented in Section V would be biased downward (upward). ${ }^{11}$

\section{Summary Statistics for Treatment and Comparison Groups}

Tables 2 and 3 summarize the demographic and economic characteristics of EZ areas and comparison and their respective surrounding cities for the 1990 and 2000 census. Not surprisingly, according to the 1990 census both EZ and runner-up area residents were substantially worse off economically than the residents of the cities surrounding them prior to EZ designation. On average, EZ residents had about half of the per-capita income of surrounding city residents $(\$ 8,621$ and $\$ 17,417$ respectively). By design of the program, the EZs had higher

\footnotetext{
${ }^{11}$ If EZs improved other areas of the city because of a positive externality, then comparing to the EZ area to the surrounding city would understate the true effect. If the EZs shifted resources away from other areas of the city, then comparing the EZ area to the surrounding city would overstate the true effect.
} 
unemployment rates than the surrounding cities. ${ }^{12}$ On average, the unemployment rate in the EZs was nearly double that of the surrounding cities. Only about a quarter (27 percent) of EZ residents were employed, compared to 41 percent of the surrounding cities' residents.

Similarly, runner-up area residents had slightly more than half of the surrounding city per capita income $(\$ 9,919$ and $\$ 17,339)$, and nearly double the unemployment rate. Employment in runner-up areas was, on average, 34 percent compared to 45 percent in the larger city, a smaller gap than the EZ areas and their respective cities.

Economic outcomes for EZ residents improved relative to residents in the cities surrounding them between the 1990 to the 2000 census. The average per capita income for residents living in EZ areas increased by $\$ 2,628$ (real 1999 dollars) compared with $\$ 2,008$ in the cities surrounding the EZ areas. The average employment rate of EZ residents rose by 7.4 percent, compared to a 2.4 percent decline in the average employment rate in larger city, thus shrinking the relative gap in employment for $\mathrm{EZ}$ residents.

The runner-up areas did not, on average, experience the same economic improvement as the EZ areas relative to their respective cities. Changes in per-capita income for the runner-up areas were about the same in dollar terms as the surrounding city (an increase of $\$ 1,979$ and $\$ 1,804$, respectively). The average employment rate in runner-up cities remained constant, while the larger cities experienced a one percentage point decline in employment. ${ }^{13}$

The increased economic well-being of EZ area residents relative to residents of the surrounding city and the runner-up areas suggests that the EZ program was successful. However, this comparison alone cannot determine the effect of the EZ program on residents for

\footnotetext{
12 The selection requirement for EZs was based on unemployment rates. However, unemployment rates do not take into account those who have left the labor force as discouraged workers. Because my analysis is on the urban poor who may fall into the discouraged worker category, I focus on the employment rate as a measure of how the program effects labor market outcomes.

${ }^{13}$ Summary statistics for individual runner-up areas are available from the author upon request.
} 
two reasons. First, many of the demographic differences (as shown in Tables 2 and 3) between the EZ areas and the surrounding cities also changed over the decade, which could be related to the economic outcomes of residents. For example, the gap in high school education between EZ residents and those in the surrounding city decreased over the decade, and there was an overall increase in the percent of EZ residents with a high school diploma or GED. Second, these results may be driven by the selection of EZ areas as being places where improved economic outcomes were expected or would have happened regardless of the program.

\section{OLS and IV Estimation Results}

Table 4 presents the results of estimating Equation (2) using employment as the dependent variable. Table 5 presents the results using resident poverty as the dependent variable. Table 6 presents the results using median property values as the dependent variable. For each outcome of interest I estimate a specification without control variables (the first column of each Table) and also using the percentage of residents who are college educated, the percentage of residents who are a race other than white, and the percentage of the population that is of working age as controls (the second column of each Table). The standard errors reported in Table 4, 5, and 6 are clustered at the city level to reflect the likelihood that economic outcomes for areas that are geographically close are highly correlated.

The OLS results in Table 4 and 5 show that the EZ program was correlated with increasing employment and lowering poverty rates of residents. The results of the regressions without control variables suggest that the program was correlated with a 2 percentage point rise in the employment rate of residents and a 2 percentage point decrease in the poverty rate of residents; 
both results are statistically significant at the 5 and 1 percent level, respectively. ${ }^{14}$ The OLS results in Table 6 show that the EZ program was not correlated with increasing median property values in an economically significant or statistically significant way. The results are not sensitive to the inclusion of control variables, as the EZ point estimate and standard errors remain almost identical to the specification that includes other characteristics of the census tract.

Endogeneity is a concern ${ }^{15}$ in estimating Equation (2) because EZs were selected by HUD based, in part, on choosing applicants that showed,

"ability to spur economic opportunity by creating jobs, attracting private partnerships, and training residents for new job opportunities; promote community development through a long-term economic development strategy; establish community-based partnerships; and develop a plan for responding to community needs by integrating economic, physical, human, and other strategies." (CRS, 2002).

This quote suggests that areas selected for the EZ program may have been expected to have positive economic outcomes even in the absence of the tax credits. This means that EZ designation is likely correlated with characteristics of the application that are also correlated with positive economic outcomes. If this is true, then the OLS results will be biased. ${ }^{16}$ Using a Hausman (1978) test for endogeneity, I find evidence that EZ designation is endogenous to employment, marginally endogenous poverty, but not to property value changes. ${ }^{17}$

\footnotetext{
${ }^{14}$ To put these results into perspective consider that the national employment rate (or employment to population ratio) varied by about 3 percentage points throughout the 1990s according to the Bureau of Labor Statistics (bls.gov).

15 Theoretical models of policy determinants, for example Besley and Case (2000) and Knight (2002), echo the concern that most policy cannot be treated as strictly exogenous.

${ }^{16}$ If EZ areas were chosen because they were expected to do well even in the absence of the program this would suggest OLS estimates are biased toward showing a positive effect of the program. The opposite could also be true, that EZ areas were chosen because they were expected to do poorly even with the zone designation or the worst areas were chosen because they needed the most help. If this were the case OLS estimates would be biased toward showing no effect of the program.

${ }^{17}$ I test the null hypothesis that the predicted errors from the EZ designation regression $\left(E Z_{i}=\alpha+\beta_{1}(\text { Terms })_{i}\right.$ $\left.\beta_{2}(\text { Member })_{i}+X_{i}^{\prime} \delta+u\right)$ are insignificant determinants of economic outcomes in the zone. Using an $F$ test, I reject the null for changes in employment ( $\mathrm{p}$-value $=0.01$ ), marginally reject the null for changes in poverty $(\mathrm{p}$-value $=$ 0.06 ), and do not reject the null for changes in property values ( $p$-value $=0.76$ ).
} 
Estimation with Endogenous EZ Designation: Instrumental Variables

A solution to the endogenous selection of EZs is to use an instrumental variables regression. This requires an instrument for EZ designation, or something about the census tract that is correlated with being designated as an EZ and uncorrelated with unobserved variables. A plausible instrument for EZ designation is one that reflects the political influence of the Federal Representative associated with the census tract. Knight (2002) uses several politically related variables as instruments, including committee assignment of Federal Representatives, for federal grant spending to determine crowd out effects on state and local spending. Other studies, including Poterba (1994), Levitt (1997), and Kubik and Moran (2003) use the exogenous cycle of elections to explain politically motivated action.

To understand the relevance of political influence in designating EZs it helps to understand the process by which the bill containing EZs became law. EZs were part of a Budget Reconciliation Bill, which contained many budget items including: funding for agencies, extensions for existing projects, and new spending. The final version of the bill passed in 1993 by a margin of one vote, with the vice-president casting the deciding vote (Libschutz, 1995). The close margin suggests that influential members of Congress could have used leverage to obtain funding for their districts to guarantee voting in favor of the bill. One potential use of this leverage would have been to secure future EZ designation for part of their districts. If influential members bargained for EZs in this way, we would expect that EZ designation would be correlated with measures of congressional power.

There is existing evidence of the relationship between political favoritism and EZ designation. Wallace (2004) finds that a location represented by a member serving on the House 
Ways and Means committee is correlated with being designated an EZ. He finds that no other committee membership is a significant determinant after controlling for other area characteristics. As an example of the correlation between Ways and Means membership and EZ designation, Figure 2 highlights the overlap between the New York City EZ and the Congressional district of Ways and Means member Charles Rangel. As shown by the map, a large portion of the New York City EZ is inside of Representative Rangel's district. ${ }^{18}$

Table 7 shows the first stage of the instrumental variable regression using both Ways and Means membership and the number of years a member was on the committee at the time of designation as instruments for EZ designation. ${ }^{19}$ Column 1 shows results without clustering standard errors and Column 2 corrects for general heteroskedasticity using the White correction, both results show the same strong correlation. The F-statistic for columns 1 and 2 shows that the instruments are jointly significant with a P-value of essentially zero. ${ }^{20}$

The first stage results in columns 1 and 2 of Table 7 could be questionable if the error term is spatially correlated. This is a problem if there were things other than observables (including the instruments) that adjacent census tracts have in common that drove EZ selection. While it is clear that the instruments are spatially correlated, it seems less likely that there are unobservable variables in the selection process that are correlated across adjacent census tracts. This also seems less likely given that I use only tracts that applied and qualified for EZ status in my

\footnotetext{
${ }^{18}$ I identified Ways and Means members for the $103^{\text {rd }}$ Congress from a list of historic committee assignments available through http://clerk.house.gov/ and matched the corresponding census tracts using the Mable/Geocorr database online at: http://mcdc2.missouri.edu/websas/geocorr90.shtml.

${ }^{19}$ In results not shown the first stage results for using only the Ways and Means member dummy variable are also significant, but not as strong. First stage results using only the number of terms a member was on the committee at time of designation are also significant and quite strong.

${ }^{20}$ I test the over-identification restriction using the Sargon-Hansen J-statistic (through the ivreg2 command in Stata (Baum, et. al., 2007)). This test fails to reject the null hypothesis that instruments are valid, with a p-value of 0.1916 .
} 
sample, so that any concerns that errors are spatially correlated because observations in an undesirable part of the city are minimized.

Although the point estimates in the first stage regressions are the same in all cases, the standard errors on the coefficient of interest when grouped by geography are large relative to the point estimate. As shown in columns 3 and 4 of Table 7 the first stage results are not robust to clustering the standard errors across geographic location, as p-values for the instruments are in the $.35-.37$ range. The large standard errors are likely due to the fact that most zones or proposed zones are split among multiple congressional districts, so that the instrument only covers part of the census tracts that received the designation. It is worth mentioning that the point estimates in the first stage, not the standard errors, determine second stage results. ${ }^{21}$

The second stage IV results sharply contrast the OLS results. Point estimates for the IV specifications using each instrument separately (the third and fourth columns of Table 4 and 5) show that the EZ had a negative effect on employment and increased resident poverty. I take the point estimates for these specifications to be evidence that the OLS estimates are biased toward finding a positive effect on employment and a negative effect on resident poverty. The standard errors associated with these specifications are, however, so large that it is impossible to say anything precise about the results of the specifications using each instrument separately.

Point estimates using both instruments are shown in column (5) of Table 4 and 5. The IV results using both instruments simultaneously suggest that the program had zero economic effect on employment and increased the poverty rate of zone residents by 2 percentage points. The standard errors for this specification, although smaller than the specification using each

\footnotetext{
${ }^{21}$ All first stage regressions are reported using a linear probability model. The sign and significance of instruments for all first stage results in columns 1 and 2 are robust to using a Probit or Logit model. For the joint significance test for both instruments the value of chi-squared test statistic in each model is over 44, with a p-value of 0.00 . As with the linear probability model, both the Probit and Logit model are sensitive to the assumption about spatial correlation of the error term in the first stage.
} 
instrument separately, are also too large to attach statistical significance to these results. ${ }^{22}$ The larger standard errors for the IV compared to OLS results are not surprising as they are subject to an additional variance caused by small variation in the predicted value for the EZ variable, see Wooldridge (2002) for an excellent description of this problem. The variation in the predicted value for EZ is particularly small in this case as it must take on a value between zero and one.

IV regression results presented in column (5) of Table 6 suggest that tax credits are capitalized into local property values (as measured by the median property value at the census tract level). ${ }^{23}$ All OLS and IV specifications show that the EZ program increased the median property value. Only the results from the IV regression using both instruments, presented in column 5 of Table 6 , are statistically significant (at the five percent level). ${ }^{24}$ The results shown in Tables 4-7 are not sensitive to including additional control variables such as the change in housing vacancy rate, occupancy rate, resident per-capita income, percent of residents with graduate degrees, or percent of Hispanic residents. These results are available from the author upon request.

Results in column (5) suggest that the EZ program increased property values by over $\$ 100,000$ (nominal). ${ }^{25}$ A $\$ 100,000$ property value increase is roughly equivalent to the present value of claiming the full wage tax credit on five employees for nine years. ${ }^{26}$ The IV results lend

\footnotetext{
${ }^{22}$ Using a t-test I cannot reject the null hypothesis that the IV coefficient of interest is equal to the corresponding OLS coefficient for both employment and poverty.

${ }^{23}$ The census data on property values is from a self-report survey where respondents are asked to report the value that their property would sell for including vacant properties. Unfortunately, this does not include any measure of commercial property values.

${ }^{24}$ The difference in statistical significance between the OLS and IV results comes from the increased point estimate values (caused by removing the bias from OLS estimates). When the increased point estimates on the property values coefficients are statistically significant, the removal of bias more than compensates for the increased standard errors that commonly plague IV results (as explained for the employment and poverty results).

${ }^{25}$ The nominal increase in median property value for the United States between the 1990 and 2000 censuses was about $\$ 40,000$.

${ }^{26}$ This present value calculation assumes a 5 percent annual discount rate, with the full tax credit claimed for each employee, and an immediate increase in property value. Note that the original EZ were designated for 10 years.
} 
themselves to a simple, intuitive explanation of what happens as a result of zone designation. The subsidy must be entirely realized by employers in the labor market, so that employment and incomes (poverty) do not change. The labor market incidence of the EZ program may be caused, in part, by the lack of a tenure requirement for the wage tax credit, so that firms do not have to expand employment to realize substantial benefits. Employers, however, are subject to the additional location restriction, thus demand for land within the EZ should shift to the right, causing an increase in property values and capitalization of the subsidy.

\section{Weighing OLS and IV Results}

The IV results suggest that the OLS specifications over-estimate the effect of the EZ program on increasing resident employment and decreasing poverty, the effect of the program is smaller and quite uncertain as shown by the large standard errors. This differs from the OLS interpretation that the tax incentives increased employment and reduced poverty in statistically and economically significant ways. However, because the IV results are imprecisely estimated, and because the wage tax credit is unambiguously beneficial for both workers and employers in the EZs, these regressions should be viewed primarily as casting doubt on the magnitude and significance of the OLS results (rather than as evidence that the EZs have negative effects on communities as some of the point estimates show).

The value of the IV regressions is that they take the zone designation process into account, and show that the OLS estimates may be biased toward finding a positive effect of the program. The OLS results show the combined effect of the EZ program and the assignment/designation bias. The IV results remove the assignment bias from the estimation and are closer to being a purely causal effect of the program. The difference between the OLS and IV results suggests 
that the assignment bias is positive and substantial for employment changes and negative and substantial for poverty changes. Although there is some suggestive evidence (the quote in section $\mathrm{V}$, for example) that the assignment bias comes from HUD picking strong applicants, some of this bias could also occur at the local level. For example, if places that would have had success in the absence of the EZ program created stronger applications and thus were more likely to be chosen.

Murray (2006) suggests a method of comparison to help determine if the IV results will be less biased than the OLS when dealing with an endogenous regressor. He suggests that the relative bias of the estimates (IV/OLS) will be equal to the number of instruments divided by the product of the number of observations and the first stage R-squared. This comparison method suggests that for each instrument and for the case where I use both instruments simultaneously, the IV results are less biased than the OLS. Although this test cannot determine that the IV results are not biased, it does suggest that they are less biased than the OLS.

One concern for bias in the second stage IV regressions is that representatives on the Ways and Means Committee get more earmarked spending (other than the EZ) for their districts than other representatives in my sample. Notice that if the concern is that earmark spending increases employment and reduces poverty, then the instrument would be positively correlated with the dependent variable and the IV regressions would be biased toward finding that the EZ program reduced poverty and increased employment. The opposite could also be true; earmark spending is correlated with decreasing employment and reducing poverty, in which case the instrument would be negatively correlated with the dependent variable and the IV regressions would be biased toward finding that the EZ program increased poverty and reduced employment. 
As shown in figure 3, at first glance it seems to be the case that the instruments are positively correlated with other spending, as federal spending ${ }^{27}$ for districts in my sample grew substantially more on average for Ways and Means committee members than non-members. Upon further inspection, however, the difference in spending between Ways and Means member districts and other members in my sample is almost entirely driven by a single district (district 22 in Florida). Spending in Florida district 22 increased by more than $\$ 50$ billion dollars between 1993 and 1997 before dropping back to normal levels in 1998. This district represents one census tract in my sample, and restricting it from the sample does not change the primary results of the IV regressions. ${ }^{28}$

Figure 3 also shows the spending path for Ways and Means member districts if Florida district 22 were to have grown at the same rate as the other districts in the sample, which is a more accurate representation of how spending changed in these districts. Although figure 3 does show that spending is still on average higher in Ways and Means member districts throughout the 1990s, the difference remains relatively constant over time, and therefore less likely to bias the IV results as the dependent variable is the change in economic outcomes of zone residents over the decade.

In addition, for Ways and Means membership to influence economic outcomes directly the member would have to remain on the committee beyond the designation period, which appears in most cases not to be true. There is substantial variation in how many terms Representatives

\footnotetext{
27 Federal Spending data are from the annual Consolidated Federal Funds Reports, they represent the sum of all direct payments to individuals (including retirement and disability benefits), grants (block, formula, project, and cooperative), procurement contracts, federal employee wages and salaries, direct loans, guaranteed loans, insured loans, insurance, and direct payments not made to individuals. This data is available at the county level and I allocate it to the congressional district using the Mable/Geocorr database according to population weights.

${ }^{28}$ I cannot control for spending directly in my regressions as the data are not available at the census tract level of geography. The county level data can be allocated based on population to the census tract and city level, but this would simply be equal to the census tract share of population divided by the city population.
} 
were on the committee before and after the $103^{\text {rd }}$ congress. Some members were in their final year (Dan Rostenkowski, D-IL), others were in their first and only year (Rick Santorum, R-PA), and others have been on the committee ever since (Chuck Rangel, D-NY). Of the 39 members, the Ways and Means committee featured 12 new members for the $104^{\text {th }}$ Congress, which began by the time the EZ tax incentives started. By the year 2000, the $106^{\text {th }}$ Congress (the end of the data for this paper) only 21 of the 39 Ways and Means members from the $103^{\text {rd }}$ Congress remained.

Some of the Ways and Means members whose districts received an EZ were members of the committee for the entire decade, and all were prominent Democrats: Charles Rangel (D-NY), Benjamin Cardin (D-MD), and John Lewis (D-GA). In terms of the instrument this may be a concern if these members were more likely to have the ability to alter the economic status of residents in their district. If this is the case, then the instrument would be correlated with future economic status of residents as well as EZ designation and would not be exogenous. However, due to the Republican take-over in the $104^{\text {th }}$ Congress the Democrats lost the committee chair and majority. This means democratic members who were influential in the $103^{\text {rd }}$ congress (when they were the majority party) lost influence in future years.

\section{Conclusion}

Geographically-targeted tax incentives are a growing part of the federal agenda used to address declining industrial cities and redevelop areas struck by economic hardship. Part of the promise of these tax incentives is that they will restore or increase employment for local residents and reduce poverty. The evidence presented here suggests that the EZ wage tax credit and may not live up to that promise, but that the program does increase property values. 
Although instrumental variables estimates cannot rule out the OLS results that suggest a large effect of the program, they do suggest that the OLS findings are biased toward finding a positive effect of the program. The IV results presented here contrast to the OLS results and the preferred estimates of Busso and Kline (2006) and HUD (2001), which find the federal EZ program is correlated with an economic and statistically significant improvement in the resident employment rate and a reduction in the poverty rate of residents.

The IV results presented here are in agreement with the substantial property value increase found by Krupka and Noonan (2009), despite differences in the choice of comparison group and estimation strategy. The similar results found here and in Krupka and Noonan are encouraging as they reveal that the property value increase is robust across multiple comparison groups and specifications. Krupka and Noonan find these effects even in the OLS specifications (comparing with future EZ areas) without accounting for endogeneity, while I only find a substantial difference between EZ and "runner-up" areas using the IV estimation. The difference in OLS findings highlight both the importance of choosing a control group and accounting for endogeneity and suggest that indeed there may be some positive benefit to areas that underwent the initial application process.

The null results for resident employment and poverty do not suggest that these types of tax incentives and grants are not useful in improving economic conditions of residents, as evidenced by the large positive effect on property values. It is also possible that the EZs have brought better jobs, or jobs with fewer hours to residents or those residents are benefiting in other ways from new skills learned at these jobs. More research is necessary to determine the exact effect these tax policies have in the labor market. However, given the relationship between EZs and property values shown here, it may be more likely that geographically targeted tax incentives and 
grants benefit land owners, therefore caution should be used when crafting policy that is tied to location if the intended effect is to improve labor market outcomes for residents. 


\section{References}

Anderson, John. 1990. "Tax Increment Financing: Municipal Adoption and Growth." National Tax Journal, 43 (2): 155-163.

Baum, C.F., Schaffer, M.E., and Stillman, S. 2007. ivreg2: Stata module for extended instrumental variables/2SLS, GMM and AC/HAC, LIML and k-class regression. http://ideas.repec.org/c/boc/bocode/s425401.html.

Besley, Timothy and Anne Case. 2000. "Unnatural Experiments? Estimating the Incidence of Endogenous Policies." Economic Journal, 110 (467): 672-694.

Boarnet, Marlon and William Bogart. 1996. "Enterprise Zones and Employment: Evidence from New Jersey.” Journal of Urban Economics, 40(2): 198-215.

Bonnonio, Daniele and John Engberg. 2000. "Enterprise zones and local employment: evidence from the states' programs." Regional Science and Urban Economics, 30(5): 519-549.

Bondonio, Daniele and Robert Greenbaum. 2007. "Do Local Tax Incentives Affect Economic Growth? What Mean Impacts Miss in the Analysis of Enterprise Zone Policies." Regional Science and Urban Economics, 37(1): 121-136.

Busso, Matias and Patrick Kline. 2006. "Do Local Economic Development Programs Work? Evidence from the Federal Empowerment Zone Program.” Unpublished Manuscript.

Dye, Richard and David Merriman. 2000. "The Effects of Tax Increment Financing on Economic Development." Journal of Urban Economics, 47(2): 306-328.

Executive Office of the President, Office of Management and Budget. Analytical Perspectives, Budget of the United States Government Fiscal Year 2009. 2008. Washington, DC: U.S. Government Printing Office.

Given, Matt. 2004. "Aim to take advantage of various targeted tax credits." Practical Tax Strategies, 72: 220-235.

Hanson, Andrew. 2006. "Utilization of Employment Tax Credits: An Analysis of Employees Eligible for the 'Empowerment Zone' Wage Tax Credit.” Unpublished Manuscript.

Hausman, J.A. 1978. “Specification Tests in Econometrics.” Econometrica 46, 1251-1271.

Internal Revenue Service, Department of the Treasury. 2004. "Publication 954: Tax Incentives for Distressed Communities.” http://www.irs.gov/pub/irs-pdf/p954.pdf.

Juhn, Chinhui and Kevin Murphy. 1997. "Wage Inequality and Family Labor Supply.” Journal of Labor Economics, 15(1): 72-97. 
Knight, Brian. 2002. "Endogenous Federal Grants and Crowd-Out of State Government Spending: Theory and Evidence from the Federal Highway Aid Program." American Economic Review, 92(1): 71-92.

Kubik, Jeffrey and John Moran. 2003. "Lethal Elections: Gubernatorial Politics and the Timing of Executions.” Journal of Law and Economics, 46(1): 1-26.

Krupka, Douglas and Douglas Noonan. 2009. "Empowerment Zones, Neighborhood Change and Owner Occupied Housing." Forthcoming in Regional Science and Urban Economics.

Levitt, Steven. 1997. "Using Electoral Cycles in Police Hiring to Estimate the Effect of Police on Crime.” American Economic Review, 87(3): 270-290.

Liebschutz, Sarah. 1995. "Empowerment Zones and Enterprise Communities: Reinventing Federalism for Distressed Communities.” Publius: The Journal of Federalism, 25(3):117-132.

Murray, Michael. 2006. "Avoiding Invalid Instruments and Coping with Weak Instruments." Journal of Economic Perspectives, 20(4): 111-132.

O'Keefe, Susan. 2004. "Job Creation in California's Enterprise Zones: A comparison Using a Propensity Score Matching Model.” Journal of Urban Economics, 55(1):131-150.

Papke, Leslie. 1994. "Tax policy and urban development: Evidence from the Indiana enterprise zone program." Journal of Public Economics, 54(1): 37-49.

Poterba, James. 1994. "State Responses to Fiscal Crises: The Effects of Budgetary Institutions and Politics." Journal of Political Economy, 102(4): 799-821.

U.S Congressional Research Service. 2002. "Empowerment Zone/Enterprise Communities Program: Overview of Rounds I, II, and III." Washington D.C.

U.S Department of Housing and Urban Development. 2001. "Interim Assessment of the Empowerment Zones and Enterprise Communities Program: A Progress Report." Washington, D.C.

U.S. Government Accountability Office. 1999. "Businesses' Use of Empowerment Zone Tax Incentives: Report to Congressional Requesters.” GAO/RCED-99-253, Washington, D.C.

U.S. Government Accountability Office. 2004. "Federal Revitalization Programs Are Being Implemented, but Data on the Use of Tax Benefits Are Limited: Report to Congressional Committees." GAO-04-306, Washington, D.C.

Wallace, Marc. 2004. "Congressional Considerations and Urban Characteristics in the Selection of Empowerment Zones and Enterprise Communities." Journal of Urban Affairs, 26(5): 593609. 
Weber, Rachel, Saurav Dev Bhatta, and David Merriman. 2007. "Spillovers from tax increment financing districts: Implications for housing price appreciation." Journal of Regional Science and Urban Economics, 37(2): 259-281.

Wooldridge, Jeffrey. 2002. Econometric Analysis of Cross Section and Panel Data. The MIT Press, Cambridge, Massachussets. 
Figure 1: Triple Difference Identification Strategy

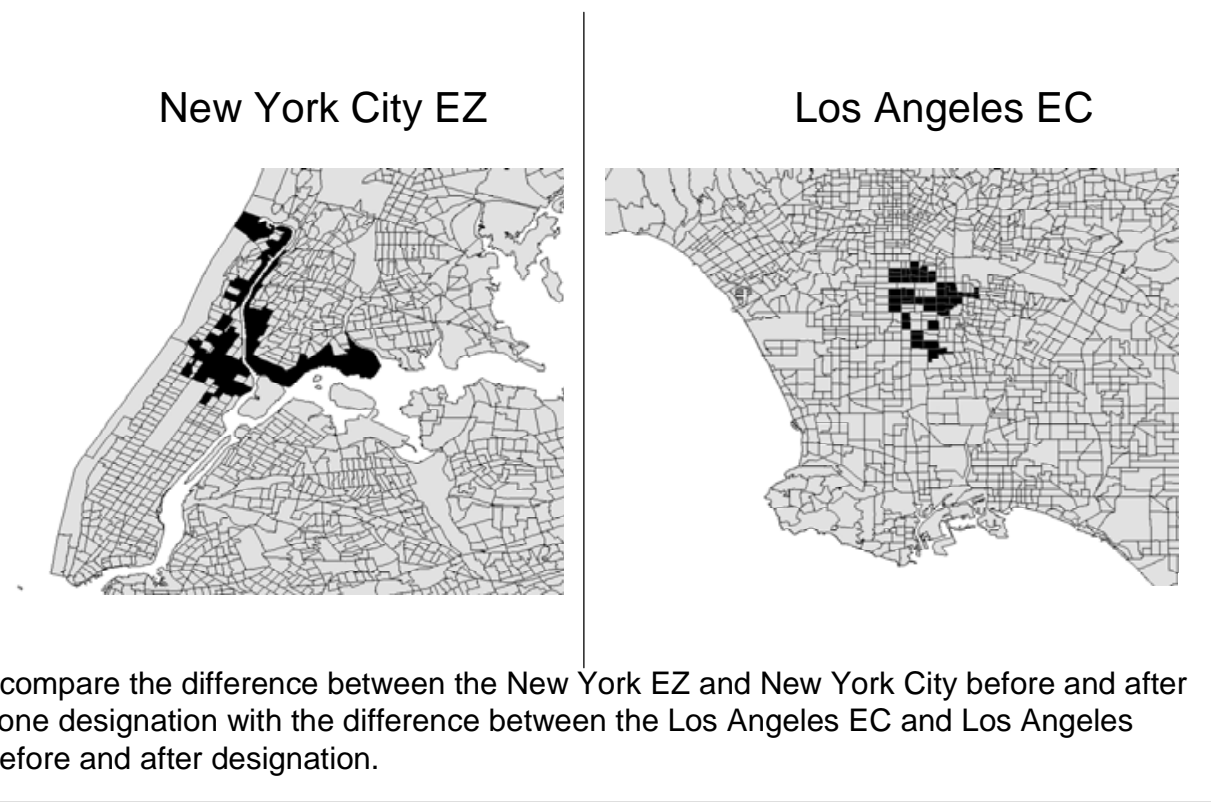


Figure 2: New York City EZ (Black) and Charles Rangel Congressional District

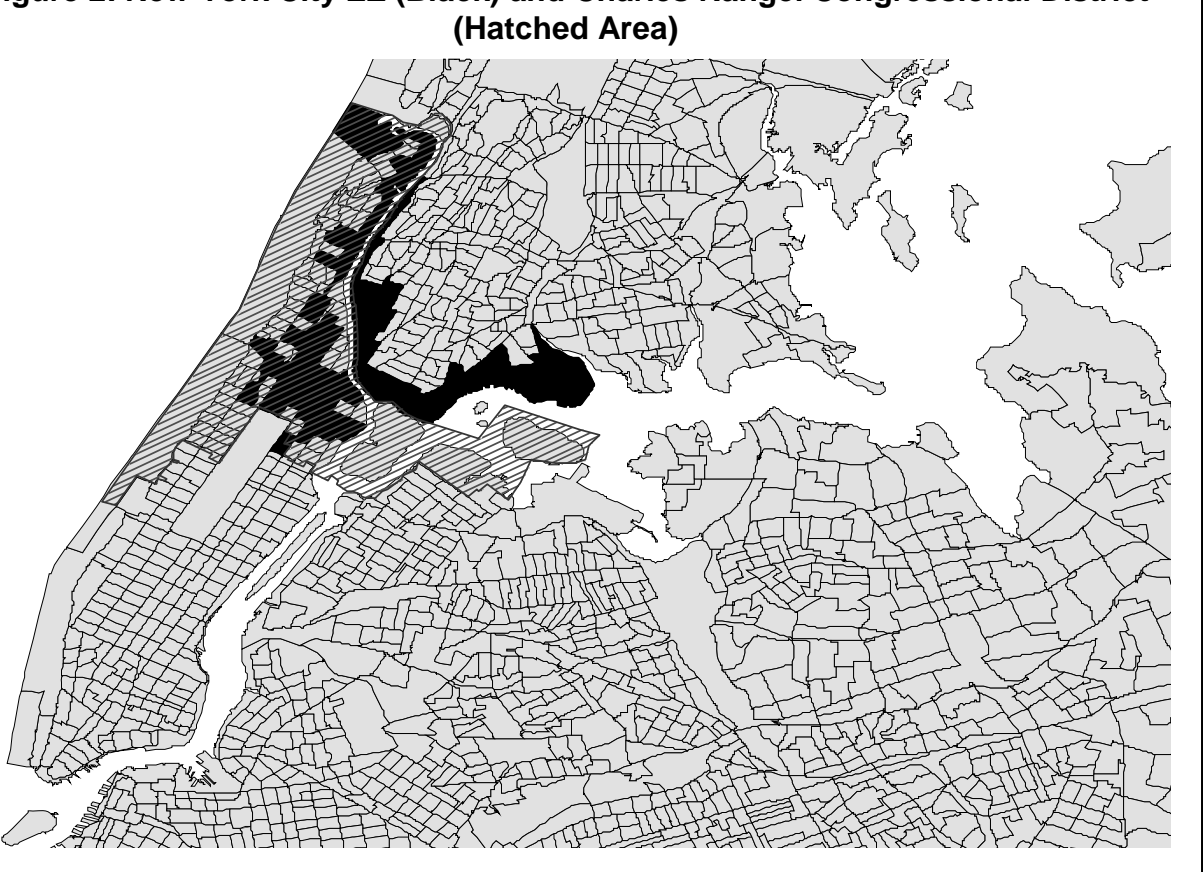


Figure 3: Annual Federal Government Spending For Congressional Districts in Sample:1993-2000

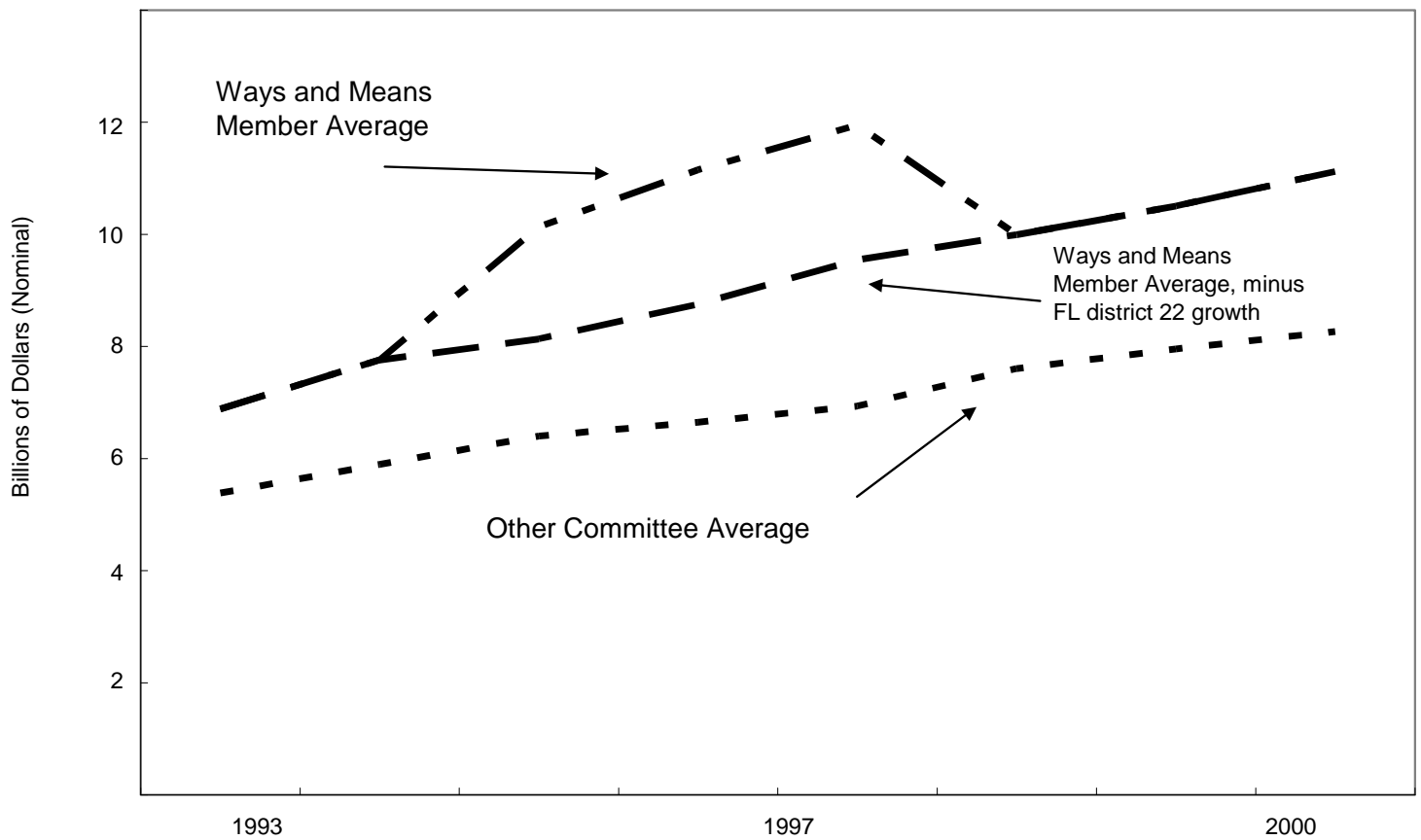

Source: Annual Consolidated Federal Funds Reports Spending Data matched to Congressional District using population weights from Geocorr Database online at http://mcdc2.missouri.edu/websas/geocorr90.shtml 


\begin{tabular}{|c|c|c|c|c|c|c|}
\hline & $\begin{array}{l}\text { Wage } \\
\text { Credit }\end{array}$ & $\begin{array}{c}\text { SS Block } \\
\text { Grants }\end{array}$ & $\begin{array}{l}\text { Cap Gains } \\
\text { Exclusion }\end{array}$ & $\begin{array}{l}\text { Stock Sale } \\
\text { Exclusion }\end{array}$ & $\begin{array}{c}\text { Facility } \\
\text { Bonds }\end{array}$ & $\begin{array}{c}179 \\
\text { Expensing }\end{array}$ \\
\hline Round I EZ & Yes & $\$ 100$ million & Yes & Yes & Yes & Yes \\
\hline $\begin{array}{l}\text { Round I EC } \\
\text { and EEC }\end{array}$ & No & \$3 million & No & No & Yes & No \\
\hline $\begin{array}{l}\text { Round I } \\
\text { SEZ }\end{array}$ & $\mathrm{No}^{2}$ & $\begin{array}{c}\$ 450 \text { million for } \\
\text { L.A, } \$ 177 \\
\text { million for CLE }\end{array}$ & Yes & Yes & Yes & Yes \\
\hline Round II EZ & $Y_{e s}{ }^{1}$ & none & Yes & Yes & Yes & Yes \\
\hline $\begin{array}{c}\text { Round III } \\
\text { EZ }\end{array}$ & Yes $^{1}$ & none & Yes & Yes & Yes & Yes \\
\hline
\end{tabular}

1. Available since 2002

2. Available starting in 2000

3. Enhanced EC differ from EC because they received some HUD grants and loan guarantees

Source: Tax Incentive Guide for Business (HUD 2001) 
Table 2: 1990 Empowerment Zone and Surrounding City Summary Statistics

\begin{tabular}{|c|c|c|c|c|c|c|c|c|c|c|c|c|c|c|}
\hline & \multicolumn{2}{|c|}{ Atlanta, GA } & \multicolumn{2}{|c|}{ Baltimore, MD } & \multicolumn{2}{|c|}{ Chicago, IL } & \multicolumn{2}{|c|}{ Detroit, MI } & \multicolumn{2}{|c|}{ New York, NY } & \multicolumn{2}{|c|}{ Philadelphia, PA* } & \multicolumn{2}{|c|}{ Runner-Up Average } \\
\hline & $\begin{array}{c}1990 \\
E Z\end{array}$ & $\begin{array}{c}1990 \\
\text { City }\end{array}$ & $\begin{array}{c}1990 \\
E Z\end{array}$ & $\begin{array}{c}1990 \\
\text { City }\end{array}$ & $\begin{array}{c}1990 \\
E Z\end{array}$ & $\begin{array}{c}1990 \\
\text { City }\end{array}$ & $\begin{array}{c}1990 \\
E Z\end{array}$ & $\begin{array}{c}1990 \\
\text { City }\end{array}$ & $\begin{array}{c}1990 \\
E Z\end{array}$ & $\begin{array}{c}1990 \\
\text { City }\end{array}$ & $\begin{array}{c}1990 \\
E Z\end{array}$ & $\begin{array}{c}1990 \\
\text { City }\end{array}$ & $\begin{array}{l}1990 \\
\text { Zone }\end{array}$ & $\begin{array}{c}1990 \\
\text { City }\end{array}$ \\
\hline $\begin{array}{l}\text { Land Area } \\
\text { (sq.mi.) }\end{array}$ & 10 & 132 & 6 & 81 & 16 & 227 & 25 & 139 & 7 & 303 & 3 & 135 & 11 & 132 \\
\hline Population & 54514 & 394017 & 77173 & 736014 & 224737 & 2783726 & 112531 & 1027974 & 221178 & 7322564 & 44541 & 1585577 & 61835 & 400592 \\
\hline $\begin{array}{l}\text { Population } \\
\text { Density }\end{array}$ & 5561 & 2985 & 12829 & 9087 & 13972 & 12263 & 4547 & 7395 & 31927 & 24167 & 16167 & 11745 & 7200 & 4537 \\
\hline$\%$ White & $5 \%$ & $31 \%$ & $21 \%$ & $39 \%$ & $12 \%$ & $45 \%$ & $26 \%$ & $22 \%$ & $15 \%$ & $52 \%$ & $12 \%$ & $54 \%$ & $36 \%$ & $65 \%$ \\
\hline$\%$ Black & $92 \%$ & $67 \%$ & $77 \%$ & $59 \%$ & $71 \%$ & $39 \%$ & $66 \%$ & $76 \%$ & $57 \%$ & $29 \%$ & $61 \%$ & $40 \%$ & $51 \%$ & $27 \%$ \\
\hline$\%$ Other & $2 \%$ & $2 \%$ & $1 \%$ & $2 \%$ & $17 \%$ & $15 \%$ & $8 \%$ & $3 \%$ & $27 \%$ & $19 \%$ & $27 \%$ & $7 \%$ & $13 \%$ & $8 \%$ \\
\hline $\begin{array}{l}\% \text { Under } \\
20\end{array}$ & $40 \%$ & $30 \%$ & $34 \%$ & $29 \%$ & $42 \%$ & $31 \%$ & $31 \%$ & $34 \%$ & $34 \%$ & $27 \%$ & $38 \%$ & $29 \%$ & $36 \%$ & $30 \%$ \\
\hline$\% 21$ to 29 & $15 \%$ & $17 \%$ & $17 \%$ & $16 \%$ & $15 \%$ & $17 \%$ & $14 \%$ & $14 \%$ & $16 \%$ & $16 \%$ & $14 \%$ & $16 \%$ & $16 \%$ & $17 \%$ \\
\hline$\% 30$ to 39 & $15 \%$ & $18 \%$ & $16 \%$ & $17 \%$ & $14 \%$ & $17 \%$ & $16 \%$ & $16 \%$ & $15 \%$ & $17 \%$ & $14 \%$ & $16 \%$ & $15 \%$ & $17 \%$ \\
\hline$\% 40$ to 49 & $9 \%$ & $12 \%$ & $10 \%$ & $12 \%$ & $9 \%$ & $11 \%$ & $10 \%$ & $11 \%$ & $11 \%$ & $13 \%$ & $10 \%$ & $11 \%$ & $10 \%$ & $11 \%$ \\
\hline $\begin{array}{l}\% 65 \text { and } \\
\text { over }\end{array}$ & $11 \%$ & $11 \%$ & $12 \%$ & $14 \%$ & $10 \%$ & $12 \%$ & $16 \%$ & $12 \%$ & $10 \%$ & $13 \%$ & $12 \%$ & $15 \%$ & $12 \%$ & $13 \%$ \\
\hline
\end{tabular}

* The Philadelphia EZ also includes parts of Camden, NJ which are excluded from this analysis 
Table 2 (Continued): 1990 Empowerment Zone and Surrounding City Summary Statistics

\begin{tabular}{|c|c|c|c|c|c|c|c|c|c|c|c|c|c|c|}
\hline & \multicolumn{2}{|c|}{ Atlanta, GA } & \multicolumn{2}{|c|}{ Baltimore, MD } & \multicolumn{2}{|c|}{ Chicago, IL } & \multicolumn{2}{|c|}{ Detroit, MI } & \multicolumn{2}{|c|}{ New York, NY } & \multicolumn{2}{|c|}{ Philadelphia, PA* } & \multicolumn{2}{|c|}{ Runner-Up Average } \\
\hline & $\begin{array}{c}1990 \\
\mathrm{EZ}\end{array}$ & $\begin{array}{c}1990 \\
\text { City }\end{array}$ & $\begin{array}{c}1990 \\
\text { EZ }\end{array}$ & $\begin{array}{c}1990 \\
\text { City }\end{array}$ & $\begin{array}{c}1990 \\
\mathrm{EZ}\end{array}$ & 1990 City & $\begin{array}{c}1990 \\
E Z\end{array}$ & $\begin{array}{c}1990 \\
\text { City }\end{array}$ & $\begin{array}{c}1990 \\
E Z\end{array}$ & 1990 City & $\begin{array}{c}1990 \\
\text { EZ }\end{array}$ & $\begin{array}{c}1990 \\
\text { City }\end{array}$ & $\begin{array}{l}1990 \\
\text { Zone }\end{array}$ & $\begin{array}{l}1990 \\
\text { City }\end{array}$ \\
\hline $\begin{array}{l}\text { Unemployment } \\
\text { Rate }\end{array}$ & $18 \%$ & $9 \%$ & $15 \%$ & $9 \%$ & $24 \%$ & $11 \%$ & $28 \%$ & $20 \%$ & $17 \%$ & $9 \%$ & $24 \%$ & $10 \%$ & $16 \%$ & $9 \%$ \\
\hline $\begin{array}{l}\text { Employment } \\
\text { Rate }\end{array}$ & $28 \%$ & $44 \%$ & $32 \%$ & $43 \%$ & $25 \%$ & $43 \%$ & $24 \%$ & $33 \%$ & $31 \%$ & $44 \%$ & $24 \%$ & $41 \%$ & $34 \%$ & $45 \%$ \\
\hline $\begin{array}{l}\text { Labor Force } \\
\text { Participation }\end{array}$ & $34 \%$ & $49 \%$ & $37 \%$ & $47 \%$ & $33 \%$ & $49 \%$ & $33 \%$ & $41 \%$ & $37 \%$ & $49 \%$ & $31 \%$ & $46 \%$ & $40 \%$ & $49 \%$ \\
\hline $\begin{array}{l}\text { Income per } \\
\text { Capita (1999 } \\
\text { dollars) }\end{array}$ & $\$ 7,057$ & $\$ 20,474$ & $\$ 10,426$ & $\$ 16,072$ & $\$ 7,527$ & $\$ 17,285$ & $\$ 9,333$ & $\$ 12,654$ & $\$ 9,938$ & $\$ 21,817$ & $\$ 7,446$ & $\$ 16,202$ & $\$ 9,819$ & $\$ 17,339$ \\
\hline $\begin{array}{l}\text { Income below } \\
\text { poverty line }\end{array}$ & $56.39 \%$ & $27.29 \%$ & $42.48 \%$ & $21.87 \%$ & $48.57 \%$ & $21.62 \%$ & $47.45 \%$ & $32.41 \%$ & $42.58 \%$ & $19.29 \%$ & $53.30 \%$ & $20.27 \%$ & $40.17 \%$ & $19.95 \%$ \\
\hline $\begin{array}{l}\text { Total Housing } \\
\text { Units }\end{array}$ & 24,717 & 182,754 & 32,934 & 303,706 & 89,091 & $1,133,039$ & 55,127 & 410,027 & 87,867 & $2,992,169$ & 18,836 & 674,899 & 23,862 & 170,606 \\
\hline $\begin{array}{l}\text { Vacant } \\
\text { Housing Units }\end{array}$ & $21 \%$ & $15 \%$ & $18 \%$ & $9 \%$ & $20 \%$ & $10 \%$ & $18 \%$ & $9 \%$ & $8 \%$ & $6 \%$ & $21 \%$ & $11 \%$ & $14 \%$ & $9 \%$ \\
\hline $\begin{array}{l}\% \text { Graduating } \\
\text { from High } \\
\text { school }\end{array}$ & $41 \%$ & $70 \%$ & $43 \%$ & $61 \%$ & $42 \%$ & $66 \%$ & $46 \%$ & $62 \%$ & $45 \%$ & $68 \%$ & $39 \%$ & $64 \%$ & $52 \%$ & $72 \%$ \\
\hline $\begin{array}{l}\% \text { Graduating } \\
\text { from College }\end{array}$ & $5 \%$ & $27 \%$ & $8 \%$ & $15 \%$ & $7 \%$ & $19 \%$ & $8 \%$ & $10 \%$ & $9 \%$ & $23 \%$ & $5 \%$ & $15 \%$ & $10 \%$ & $21 \%$ \\
\hline
\end{tabular}

* The Philadelphia EZ also includes parts of Camden, NJ which are excluded from this analysis 
Table 3: 2000 Empowerment Zone and Surrounding City Summary Statistics

\begin{tabular}{|c|c|c|c|c|c|c|c|c|c|c|c|c|c|c|}
\hline & \multicolumn{2}{|c|}{ Atlanta, GA } & \multicolumn{2}{|c|}{ Baltimore, MD } & \multicolumn{2}{|c|}{ Chicago, IL } & \multicolumn{2}{|c|}{ Detroit, MI } & \multicolumn{2}{|c|}{ New York, NY } & \multicolumn{2}{|c|}{ Philadelphia, PA* } & \multicolumn{2}{|c|}{ Runner-Up Average } \\
\hline & $\begin{array}{c}2000 \\
E Z\end{array}$ & $\begin{array}{l}2000 \\
\text { City }\end{array}$ & $\begin{array}{c}2000 \\
E Z\end{array}$ & $\begin{array}{c}2000 \\
\text { City }\end{array}$ & $\begin{array}{c}2000 \\
E Z\end{array}$ & $\begin{array}{l}2000 \\
\text { City }\end{array}$ & $\begin{array}{c}2000 \\
E Z\end{array}$ & $\begin{array}{l}2000 \\
\text { City }\end{array}$ & $\begin{array}{c}2000 \\
E Z\end{array}$ & $\begin{array}{l}2000 \\
\text { City }\end{array}$ & $\begin{array}{c}2000 \\
E Z\end{array}$ & $\begin{array}{l}2000 \\
\text { City }\end{array}$ & $\begin{array}{l}2000 \\
\text { Zone }\end{array}$ & $\begin{array}{l}2000 \\
\text { City }\end{array}$ \\
\hline $\begin{array}{l}\text { Land Area } \\
\text { (sq.mi.) }\end{array}$ & 10 & 132 & 6 & 81 & 16 & 227 & 25 & 139 & 7 & 303 & 3 & 135 & 11 & 132 \\
\hline Population & 47350 & 416629 & 52496 & 651154 & 199801 & 2895964 & 99454 & 951270 & 230082 & 8008278 & 37389 & 1517550 & 47037 & 436522 \\
\hline $\begin{array}{l}\text { Population } \\
\text { Density }\end{array}$ & 4830 & 3156 & 8727 & 8039 & 12421 & 12758 & 4018 & 6844 & 33212 & 26430 & 13571 & 11241 & 5325 & 4650 \\
\hline$\%$ White & $8 \%$ & $33 \%$ & $17 \%$ & $32 \%$ & $15 \%$ & $42 \%$ & $22 \%$ & $12 \%$ & $16 \%$ & $45 \%$ & $14 \%$ & $45 \%$ & $33 \%$ & $58 \%$ \\
\hline$\%$ Black & $89 \%$ & $61 \%$ & $79 \%$ & $64 \%$ & $67 \%$ & $37 \%$ & $63 \%$ & $81 \%$ & $48 \%$ & $26 \%$ & $59 \%$ & $43 \%$ & $47 \%$ & $28 \%$ \\
\hline$\%$ Other & $3 \%$ & $5 \%$ & $4 \%$ & $4 \%$ & $18 \%$ & $21 \%$ & $16 \%$ & $6 \%$ & $36 \%$ & $29 \%$ & $28 \%$ & $12 \%$ & $19 \%$ & $14 \%$ \\
\hline $\begin{array}{l}\% \text { Under } \\
20\end{array}$ & $48 \%$ & $28 \%$ & $40 \%$ & $30 \%$ & $48 \%$ & $31 \%$ & $41 \%$ & $35 \%$ & $38 \%$ & $28 \%$ & $42 \%$ & $30 \%$ & $41 \%$ & $30 \%$ \\
\hline$\% 21$ to 29 & $16 \%$ & $18 \%$ & $12 \%$ & $13 \%$ & $14 \%$ & $16 \%$ & $14 \%$ & $13 \%$ & $14 \%$ & $14 \%$ & $11 \%$ & $14 \%$ & $15 \%$ & $15 \%$ \\
\hline$\% 30$ to 39 & $14 \%$ & $18 \%$ & $16 \%$ & $15 \%$ & $14 \%$ & $17 \%$ & $15 \%$ & $14 \%$ & $16 \%$ & $17 \%$ & $13 \%$ & $15 \%$ & $15 \%$ & $16 \%$ \\
\hline$\% 40$ to 49 & $12 \%$ & $14 \%$ & $15 \%$ & $15 \%$ & $12 \%$ & $14 \%$ & $14 \%$ & $14 \%$ & $14 \%$ & $15 \%$ & $14 \%$ & $14 \%$ & $13 \%$ & $14 \%$ \\
\hline$\% 50$ to 64 & $13 \%$ & $13 \%$ & $15 \%$ & $14 \%$ & $14 \%$ & $13 \%$ & $16 \%$ & $13 \%$ & $14 \%$ & $14 \%$ & $14 \%$ & $14 \%$ & $14 \%$ & $13 \%$ \\
\hline $\begin{array}{l}\text { \% } 65 \text { and } \\
\text { over }\end{array}$ & $9 \%$ & $10 \%$ & $11 \%$ & $13 \%$ & $9 \%$ & $10 \%$ & $12 \%$ & $10 \%$ & $9 \%$ & $12 \%$ & $12 \%$ & $14 \%$ & $10 \%$ & $12 \%$ \\
\hline
\end{tabular}

* The Philadelphia EZ also includes parts of Camden, NJ which are excluded from this analysis 
Table 3 (Continued): 2000 Empowerment Zone and Surrounding City Summary Statistics

\begin{tabular}{|c|c|c|c|c|c|c|c|c|c|c|c|c|c|c|}
\hline & \multicolumn{2}{|c|}{ Atlanta, GA } & \multicolumn{2}{|c|}{ Baltimore, MD } & \multicolumn{2}{|c|}{ Chicago, IL } & \multicolumn{2}{|c|}{ Detroit, MI } & \multicolumn{2}{|c|}{ New York, NY } & \multicolumn{2}{|c|}{ Philadelphia, $\mathrm{PA}^{*}$} & \multicolumn{2}{|c|}{ Runner-Up Average } \\
\hline & $\begin{array}{c}2000 \\
E Z\end{array}$ & $\begin{array}{l}2000 \\
\text { City }\end{array}$ & $\begin{array}{c}2000 \\
E Z\end{array}$ & $\begin{array}{l}2000 \\
\text { City }\end{array}$ & $\begin{array}{c}2000 \\
E Z\end{array}$ & 2000 City & $\begin{array}{c}2000 \\
E Z\end{array}$ & $\begin{array}{l}2000 \\
\text { City }\end{array}$ & $\begin{array}{c}2000 \\
E Z\end{array}$ & 2000 City & $\begin{array}{c}2000 \\
E Z\end{array}$ & $\begin{array}{l}2000 \\
\text { City }\end{array}$ & $\begin{array}{l}2000 \\
\text { Zone }\end{array}$ & $\begin{array}{l}2000 \\
\text { City }\end{array}$ \\
\hline $\begin{array}{l}\text { Unemployment } \\
\text { Rate }\end{array}$ & $25 \%$ & $14 \%$ & $17 \%$ & $11 \%$ & $19 \%$ & $10 \%$ & $18 \%$ & $14 \%$ & $19 \%$ & $10 \%$ & $20 \%$ & $11 \%$ & $15 \%$ & $8 \%$ \\
\hline $\begin{array}{l}\text { Employment } \\
\text { Rate }\end{array}$ & $30 \%$ & $44 \%$ & $31 \%$ & $39 \%$ & $29 \%$ & $42 \%$ & $32 \%$ & $35 \%$ & $30 \%$ & $41 \%$ & $24 \%$ & $39 \%$ & $34 \%$ & $44 \%$ \\
\hline $\begin{array}{l}\text { Labor Force } \\
\text { Participation } \\
\text { Income per }\end{array}$ & $40 \%$ & $51 \%$ & $37 \%$ & $44 \%$ & $36 \%$ & $47 \%$ & $39 \%$ & $40 \%$ & $37 \%$ & $45 \%$ & $30 \%$ & $43 \%$ & $40 \%$ & $49 \%$ \\
\hline $\begin{array}{l}\text { Capita (1999 } \\
\text { dollars) }\end{array}$ & $\$ 9,105$ & $\$ 25,772$ & $\$ 13,064$ & $\$ 16,978$ & $\$ 10,896$ & $\$ 20,175$ & $\$ 12,766$ & $\$ 14,717$ & $\$ 12,268$ & $\$ 22,402$ & $\$ 9,400$ & $\$ 16,509$ & $\$ 11,798$ & $\$ 19,143$ \\
\hline $\begin{array}{l}\text { Income below } \\
\text { poverty line }\end{array}$ & $46.45 \%$ & $24.40 \%$ & $37.20 \%$ & $22.92 \%$ & $38.24 \%$ & $19.61 \%$ & $36.71 \%$ & $26.08 \%$ & $38.51 \%$ & $21.25 \%$ & $43.99 \%$ & $22.89 \%$ & $35.14 \%$ & $19.45 \%$ \\
\hline $\begin{array}{l}\text { Total Housing } \\
\text { Units }\end{array}$ & 20,203 & 186,998 & 27,895 & 300,477 & 79,368 & $1,152,871$ & 44,145 & 375,096 & 94,320 & $3,200,912$ & 17,068 & 661,958 & 18,724 & 181,570 \\
\hline $\begin{array}{l}\text { Vacant } \\
\text { Housing Units }\end{array}$ & $15 \%$ & $10 \%$ & $27 \%$ & $14 \%$ & $18 \%$ & $8 \%$ & $17 \%$ & $10 \%$ & $11 \%$ & $6 \%$ & $25 \%$ & $11 \%$ & $13 \%$ & $8 \%$ \\
\hline $\begin{array}{l}\% \text { Graduating } \\
\text { from High } \\
\text { school }\end{array}$ & $57 \%$ & $77 \%$ & $57 \%$ & $68 \%$ & $55 \%$ & $72 \%$ & $58 \%$ & $70 \%$ & $55 \%$ & $72 \%$ & $51 \%$ & $71 \%$ & $61 \%$ & $77 \%$ \\
\hline $\begin{array}{l}\% \text { Graduating } \\
\text { from College }\end{array}$ & $11 \%$ & $35 \%$ & $13 \%$ & $19 \%$ & $10 \%$ & $25 \%$ & $9 \%$ & $11 \%$ & $11 \%$ & $27 \%$ & $7 \%$ & $18 \%$ & $11 \%$ & $24 \%$ \\
\hline
\end{tabular}

* The Philadelphia EZ also includes parts of Camden, NJ which are excluded from this analysis 


\begin{tabular}{|c|c|c|c|c|c|}
\hline & \multicolumn{2}{|c|}{ OLS } & \multicolumn{3}{|c|}{ IV } \\
\hline & (1) & (2) & (3) & (4) & (5) \\
\hline & & & Terms & Membership & Both \\
\hline \multirow[t]{2}{*}{ EZ } & $0.02^{\star \star \star}$ & $0.02^{\star \star}$ & -0.03 & -0.09 & 0.00 \\
\hline & $(0.01)$ & $(0.01)$ & $(0.07)$ & $(0.25)$ & $(0.02)$ \\
\hline \% College Educated & & $\begin{array}{c}0.28^{\star \star \star} \\
(0.06)\end{array}$ & $\begin{array}{c}0.28^{\star \star \star} \\
(0.06)\end{array}$ & $\begin{array}{c}0.28^{\star \star \star} \\
(0.06)\end{array}$ & $\begin{array}{c}0.28^{\star \star \star} \\
(0.06)\end{array}$ \\
\hline$\%$ Working Age & & $\begin{array}{c}0.02^{\star \star \star} \\
(0.01)\end{array}$ & $\begin{array}{c}0.03^{\star \star *} \\
(0.01)\end{array}$ & $\begin{array}{c}0.02^{\star \star \star} \\
(0.01)\end{array}$ & $\begin{array}{c}0.02^{\star \star *} \\
(0.01)\end{array}$ \\
\hline$\%$ Non-White & & $\begin{array}{c}-0.13^{\star \star \star} \\
(0.04)\end{array}$ & $\begin{array}{c}-0.14^{\star \star \star} \\
(0.04)\end{array}$ & $\begin{array}{c}-0.14^{\star \star \star} \\
(0.04)\end{array}$ & $\begin{array}{c}-0.14^{\star \star \star} \\
(0.04)\end{array}$ \\
\hline $\mathrm{N}$ & 1262 & 1262 & 1262 & 1262 & 1262 \\
\hline $\mathrm{R}^{2}$ & 0.02 & 0.21 & & & \\
\hline \multicolumn{6}{|c|}{$\begin{array}{l}\star * * \text { indicates significant at } 1 \% \text { level, }{ }^{*} \text { at } 5 \% \text { level, * at } 10 \% \text { level } \\
\text { Data are from the } 1990 \text { and } 2000 \text { Censuses } \\
\text { Unit of observation is the census tract }\end{array}$} \\
\hline
\end{tabular}

Table 5: Effect of Empowerment Zone Tax Incentives on Zone Resident Poverty (standard errors clustered at the city level are shown in parenthesis)

\begin{tabular}{|c|c|c|c|c|c|}
\hline & \multicolumn{2}{|c|}{ OLS } & \multicolumn{3}{|c|}{ IV } \\
\hline & (1) & (2) & (3) & (4) & (5) \\
\hline & & & Terms & Membership & Both \\
\hline \multirow[t]{2}{*}{$E Z$} & $-0.02^{\star *}$ & $-0.02^{*}$ & 0.04 & 0.07 & 0.02 \\
\hline & $(0.01)$ & $(0.01)$ & $(0.07)$ & $(0.20)$ & $(0.03)$ \\
\hline \multirow[t]{2}{*}{$\%$ College Educated } & & $-0.22^{* *}$ & $-0.22^{\star \star}$ & $-0.23^{\star \star}$ & $-0.22^{\star \star}$ \\
\hline & & $(0.10)$ & $(0.10)$ & $(0.09)$ & $(0.01)$ \\
\hline \multirow{2}{*}{$\%$ Working Age } & & -0.02 & -0.02 & -0.02 & -0.02 \\
\hline & & $(0.01)$ & $(0.02)$ & $(0.02)$ & $(0.01)$ \\
\hline \multirow[t]{2}{*}{$\%$ Non-White } & & 0.06 & 0.06 & 0.06 & 0.06 \\
\hline & & $(0.09)$ & $(0.08)$ & $(0.08)$ & $(0.08)$ \\
\hline $\mathrm{N}$ & 1258 & 1258 & 1258 & 1258 & 1258 \\
\hline $\mathrm{R}^{2}$ & 0 & 0.04 & & & \\
\hline
\end{tabular}


Table 6: Effect of Empowerment Zone Tax Incentives on Median Property Value (standard errors clustered at the city level are shown in parenthesis)

\begin{tabular}{|c|c|c|c|c|c|}
\hline & \multicolumn{2}{|c|}{ OLS } & \multicolumn{3}{|c|}{ IV } \\
\hline \multirow{4}{*}{ EZ } & (6) & (7) & (8) & (9) & (10) \\
\hline & & & Terms & Membership & Both \\
\hline & 4885 & 6632 & 116681 & 140094 & $105305^{\star \star}$ \\
\hline & $(8788)$ & (9477) & (83719) & (226011) & (44928) \\
\hline \multirow[t]{2}{*}{$\%$ College Educated } & & $206392^{\star \star \star}$ & $200946^{\star \star \star}$ & $199787^{* *}$ & $201509 * * *$ \\
\hline & & (57366) & (75155) & (78520) & (73533) \\
\hline \multirow[t]{2}{*}{$\%$ Working Age } & & -243 & -1554 & -1833 & -1418 \\
\hline & & (3274) & (5460) & (6613) & (5100) \\
\hline \multirow[t]{2}{*}{$\%$ Non-White } & & -7969 & -5417 & -4874 & -5681 \\
\hline & & (19132) & (33080) & (37493) & (31072) \\
\hline $\mathrm{N}$ & 1262 & 1262 & 1262 & 1262 & 1262 \\
\hline $\mathrm{R}^{2}$ & 0.00 & 0.05 & & & \\
\hline \multicolumn{6}{|c|}{$\begin{array}{l}{ }^{* * *} \text { indicates significant at } 1 \% \text { level, }{ }^{* *} \text { at } 5 \% \text { level, }{ }^{*} \text { at } 10 \% \text { level } \\
\text { Data are from the } 1990 \text { and } 2000 \text { Censuses, property values are expressed in nominal } \\
\text { changes, per-capita income is expressed in } 1999 \text { dollars } \\
\text { Unit of observation is the census tract }\end{array}$} \\
\hline
\end{tabular}

Table 7: First Stage Regression, Dependent Variable Empowerment Zone Designation (standard errors in parenthesis)

\begin{tabular}{|c|c|c|c|c|}
\hline & (1) & (2) & (3) & (4) \\
\hline & $\begin{array}{c}\text { No } \\
\text { cluster }\end{array}$ & $\begin{array}{c}\text { Robust } \\
\text { SE }\end{array}$ & $\begin{array}{c}\text { Cluster at } \\
\text { City }\end{array}$ & $\begin{array}{c}\text { Cluster at } \\
\text { District }\end{array}$ \\
\hline Democratic Terms on Committee & $\begin{array}{c}0.04^{\star \star \star} \\
(0.01)\end{array}$ & $\begin{array}{c}0.04^{\star * \star} \\
(0.00)\end{array}$ & $\begin{array}{c}0.04 \\
(0.03)\end{array}$ & $\begin{array}{c}0.04 \\
(0.03)\end{array}$ \\
\hline Ways \& Means Member & $\begin{array}{c}-0.27^{\star \star \star} \\
(0.06)\end{array}$ & $\begin{array}{c}-0.27^{\star \star \star *} \\
(0.05)\end{array}$ & $\begin{array}{l}-0.27 \\
(0.26)\end{array}$ & $\begin{array}{l}-0.27 \\
(0.25)\end{array}$ \\
\hline$\%$ College Educated & $\begin{array}{c}0.03 \\
(0.16)\end{array}$ & $\begin{array}{c}0.03 \\
(0.16)\end{array}$ & $\begin{array}{c}0.03 \\
(0.27)\end{array}$ & $\begin{array}{c}0.03 \\
(0.25)\end{array}$ \\
\hline$\%$ of Population Working Age & $\begin{array}{c}0.01 \\
(0.01)\end{array}$ & $\begin{array}{c}0.01 \\
(0.02)\end{array}$ & $\begin{array}{c}0.01 \\
(0.02)\end{array}$ & $\begin{array}{c}0.01 \\
(0.02)\end{array}$ \\
\hline$\%$ of Population Non-White & $\begin{array}{c}0.02 \\
(0.09)\end{array}$ & $\begin{array}{c}0.02 \\
(0.10)\end{array}$ & $\begin{array}{c}0.02 \\
(0.21)\end{array}$ & $\begin{array}{c}0.02 \\
(0.16)\end{array}$ \\
\hline Constant & $\begin{array}{c}0.21 \\
(0.01) \\
\end{array}$ & $\begin{array}{c}0.21 \\
(0.01) \\
\end{array}$ & $\begin{array}{c}0.21 \\
(0.10)\end{array}$ & $\begin{array}{c}0.21 \\
(0.07) \\
\end{array}$ \\
\hline $\mathrm{N}$ & 1262 & 1262 & 1262 & 1262 \\
\hline R-squared & 0.04 & 0.04 & 0.04 & 0.04 \\
\hline Instrument F-test $(2,1256)$ & 28.02 & 31.19 & & \\
\hline Instrument F-test $(2,66)$ & & & 1.06 & \\
\hline Instrument F-test $(2,98)$ & & & & 1 \\
\hline P-Value & 0 & 0 & 0.35 & 0.37 \\
\hline
\end{tabular}




\section{Appendix: Empowerment Zone Program Benefits}

179 Expensing: Businesses operating within the $\mathrm{EZ}$ are allowed to immediately expense a larger amount of the purchase of qualified property than non-EZ businesses. The 179 expensing limit for non-EZ businesses is $\$ 102,000$, EZ businesses are allowed to expense up to $\$ 137,000$ (limits are in 2004 dollars, but are adjusted annually for inflation). The regular 179 expensing provision does not allow for the expensing of building purchases; however buildings purchased in an EZ may be expensed (IRS, 2004). EZ businesses are also allowed to claim deductions for Brownfield clean up and certain commercial revitalization projects that they may otherwise not qualify for.

Capital Gains Exclusion: Businesses operating in an EZ are allowed to postpone the reporting of gains from the sale of qualified assets. These assets must have been purchased at least one year prior to sale and used mostly for business purposes within the EZ (IRS, 2004).

Stock Sale Exclusion: Taxpayers may exclude 60 percent of the gains from the sale of small business stock held in EZ businesses for up to five years (50 percent is what is typically allowed). The businesses must be qualified EZ businesses for most of the time that the taxpayer owns the stock (IRS, 2004).

Facility Bonds: State and local governments are allowed to issue tax exempt bonds if the proceeds are used to provide EZ businesses with qualified property ${ }^{9}$ (IRS, 2004). The Federal Government puts a ceiling on the maximum amount of tax exempt bonds that may be issued by state and local governments in each state. This maximum is currently set at $\$ 80$ per state 
resident. Bonds issued on behalf of EZ businesses were originally subject to this cap, however, this restriction was lifted in 1999 (GAO, 2004).

EZ Wage Credit: An employer operating in the EZ can claim a tax credit for wages paid to an employee who resides within EZ boundaries. The amount of the credit is 20 percent of the first $\$ 15,000$ in wages paid, for a maximum credit of $\$ 3,000$ per employee. HUD maintains an address locator where employers can input an employee's address to find out if they are qualified. Qualified employees must live in designated census tracts and perform most of their work within the EZ. Employers operating outside of an EZ that hire youth (persons age 18 to 24, inclusive) who live in EZ can also claim the Work Opportunity Tax Credit for wages paid during the first two years of employment. The EZ wage credit can only be claimed for an employee if the employee has worked at least 90 days; there is, however, no upper bound on the tenure of an employee. The following types of establishments are not permitted to claim the EZ wage credit: private or commercial golf courses, country clubs, massage parlors, hot tub facilities, suntan facilities, racetracks or other facilities used for gambling, and liquor stores. Restrictions are also put on farm employees based on the assets of the farm. In addition, an employer cannot claim the credit for most relatives or for individuals who own more than 5 percent of the business (IRS, 2004). 